\title{
Communication
}

[Comunicação]

\section{Prevalence of Angiostrongylus cantonensis and Angiostrongylus costaricensis in Achatina fulica snails in the municipality of São Bernardo do Campo (SP, Brazil)}

\author{
[Prevalência de Angiostrongylus cantonensis e Angiostrongylus costaricensis em \\ caramujos Achatina fulica na cidade de São Bernardo do Campo (SP, Brasil)] \\ C.V. Cardoso ${ }^{1}$, D.C. $\operatorname{Vaccas}^{2}$, E.F. Bondan ${ }^{1,2^{*}}$, M.F.M. Martins ${ }^{1,2}$ \\ ${ }^{1}$ Aluno de pós-graduação - Universidade Paulista - São Paulo, SP \\ ${ }^{2}$ Universidade Cruzeiro do Sul - São Paulo, SP
}

Both Angiostrongylus cantonensis and Angiostrongylus costaricensis are parasitic nematodes belonging to the superfamily Metastrongyloidea that reside in rodents and use gastropods, more commonly known as snails and slugs, as intermediate hosts (Pien and Pien, 1999; Espírito-Santo et al., 2013; Giannelli et al., 2016). Rats (Rattus spp.) are the definitive hosts and transmit their larvae through their feces (Pien and Pien, 1999; Barratt et al., 2016). The snail Achatina fulica, known as the giant African land snail, is an intermediate host playing an important role in the dispersion of $A$. cantonensis and A. costaricensis, zoonotic pathogens that cause, respectively, eosinophilic meningoencephalitis and abdominal angiostrongyliasis in humans (Klikst and Palumbo, 1992; Graeff-Teixeira, 2007; Morassutti et al., 2014). A. cantonensis has spread from Southeast Asia to the South Pacific, Africa, India, the Caribbean, and, recently, to Australia and the Americas, probably as a consequence of global warming or other environmental factors, such the efficient dispersion of ship-borne rats and the diversity of its intermediate hosts (Pien; Pien, 1999; Barrett et al., 2016). In its turn, $A$. costaricensis has been reported from Southern United States to Northern Argentina and in Brazil there is an endemic area in the Southern states of Paraná, Santa Catarina and Rio Grande do Sul (Silva et $a l ., 2013)$. The relatively restricted range of $A$. costaricensis is probably related to the limited distribution of its preferred definitive host, the hispid cotton rat (Sigmodon hispidus), which is usually found only in Southern United States and parts of Central and South America (Barratt et al., 2016).

The first record of molluscs naturally infected with A. cantonensis in Brazil, including A. fulica, was done in the state of Espírito Santo, Brazil, in 2007 (Caldeira et al., 2007), and the first report of eosinophilic meningitis caused by $A$. cantonensis in the city of São Paulo, Brazil, dates back to 2013 (Espírito-Santo et al., 2013). A. fulica snail is currently present in 24 out of 26 Brazilian States and in the Federal District. Such explosive dissemination illustrates the current concern with global changes favouring dissemination of infectious diseases. Dense populations of $A$. fulica are problematic to human populations as well as menaceful to gardens and small crops, and act in the transmission of the aforementioned zoonotic diseases and other parasitosis of veterinary importance (Graeff-Teixeira, 2007). In such context, the aim of this investigation was to collect $A$. fulica snails $(\mathrm{n}=90)$ from different regions of the municipality of São Bernardo do Campo (SP, Brazil) from January to June 2018 for molecular detection of $A$. cantonensis or $A$. costaricensis.

The snails were collected, preferably on rainy days, from 8 different regions (Rudge Ramos, Baeta Neves, Planalto, Demarchi, Dos Alvarengas, Batistini, Montanhão, Rio Grande)

Recebido em 26 de março de 2019

Aceito em 13 de maio de 2019

* Autor para correspondência (corresponding author)

E-mail: ef.bondan@gmail.com 
of this municipality. They were then packed and sent to the Laboratory of Molecular Biology of the University Cruzeiro do Sul, where the analyses were performed. According to the size of the snails, molluscs from the same location were pooled $(n=25$, Table 1$)$ and then digested. Digestion was performed according to the protocol proposed by Wallace and Rosen, followed by the Baermann-Moraes sedimentation method (Caldeira et al., 2007). After sedimentation, the material was analyzed under a stereomicroscope for nematode larvae and the larvae from each collection point (pool) were counted and submitted to molecular studies. DNA extraction and purification was performed using the Qiagen kit Dneasy Blood \& Tissue (Invitrogen, Carlsbad, CA, USA), according to manufacturer's instructions. Summarily, $180 \mu \mathrm{L}$ of ATL buffer and $20 \mu \mathrm{L}$ of proteinase $\mathrm{K}$ from the kit were added to the sample, mixed by vortex and after overnight incubation at $56^{\circ} \mathrm{C}$.
The polymerase chain reaction (PCR) technique was carried out using the $150 \mathrm{pmol}$ of each primer (NC1 - $55^{\prime}$ ACGTCTGGTTCAGGGTTGTT 3' and NC2 5' TTAGTTTCTTTTCCTCCGT CT 3', Invitrogen, Carlsbad, CA, USA), 1U Taq DNA Polymerase and $20 \mu \mathrm{L}$ of the DNA extracted from each pooled sample. These primers were designed by Gasser (1993) and anchored in the conserved regions in the final portion of the subunit $5.8 \mathrm{~S}$ and the initial portion of subunit 28S. Amplification was performed with a GeneAmp 9700 PCR thermal cycler (Applied Biosystems, Forster City, CA, USA) using the following cycling conditions $95^{\circ} \mathrm{C}$ for $5 \mathrm{~min}$., 45 cycles of $95^{\circ} \mathrm{C}$ for $15 \mathrm{~s}, 65^{\circ} \mathrm{C}$ for $15 \mathrm{~s}$, and $72^{\circ} \mathrm{C}$ for $10 \mathrm{~min}$. The products were detected on $1.5 \%$ agarose gel stained with ethidium bromide. Profiles were compared to those of $A$. cantonensis and A. costaricensis established by Caldeira et al. (2003).

Table 1. Prevalence of infection by A. cantonensis in A. fulica pooled samples by region in the municipality of São Bernardo do Campo (SP, Brazil) and the absolute number of parasitic loads per pool

\begin{tabular}{llllll} 
Region & $\begin{array}{l}\text { Number of } \\
\text { A. fulica } \\
\text { snails } \\
\text { collected }\end{array}$ & $\begin{array}{l}\text { Number } \\
\text { of pools } \\
\text { per } \\
\text { region }\end{array}$ & $\begin{array}{l}\text { Number of } \\
\text { pools with } \\
\text { nematode } \\
\text { larvae }\end{array}$ & $\begin{array}{l}\text { Number of } \\
\text { nematode } \\
\text { larvae } \\
\text { per pool }\end{array}$ & $\begin{array}{l}\text { Number of pools } \\
\text { positive for } \\
\text { A. cantonensis }\end{array}$ \\
\hline Rudge Ramos & 10 & 3 & 1 & 84 & -- \\
Baeta Neves & 10 & 3 & -- & -- & -- \\
Planalto & 14 & 3 & 2 & $27 ; 102$ & 2 \\
Demarchi & 10 & 3 & 1 & 46 & 1 \\
Dos Alvarengas & 10 & 3 & 2 & $42 ; 68$ & 2 \\
Batistini & 10 & 3 & 3 & $29 ; 31 ; 74$ & 3 \\
Montanhão & 10 & 3 & 2 & $12 ; 47$ & 2 \\
Rio Grande & 16 & 4 & 3 & $23 ; 76 ; 112$ & 3 \\
Total & 90 & 25 & 14 & 773 & 13 \\
\hline
\end{tabular}

Results show that, with the exception of the Baeta Neves region, all others presented snails infected with nematode larvae. Six regions (Planalto, Demarchi, Dos Alvarengas, Batistini, Montanhão, Rio Grande) presented positive samples for A. cantonensis. No positive sample for $A$. costaricensis was found in any region. Numbers of $A$. fulica snails collected for the study, of pooled samples from each region, of pools with nematode larvae, of nematode larvae per pool and of pools infected with $A$. cantonensis among those with nematode larvae are shown in Table 1. Considering the A. fulica pooled samples, $56 \%(14 / 25)$ of them contained nematode larvae and $52 \%(13 / 25)$ were positive for $A$. cantonensis. Relative to the 8 regions,
$87.5 \%(7 / 8)$ of them contained nematode larvae and $75 \%(6 / 8)$ were positive for A. cantonensis. Several snails play roles as intermediate hosts for A. cantonensis and, among them, the giant African snail $A$. fulica is one of the most important due to its abundance and occupation in different ecosystems (Giannelli et al., 2016; Guerino et al., 2017).

The presence of $A$. cantonensis in Brazil was first suspected in 2006 at the V Congress of Infectology, at which a clinical case of eosinophilic meningoencephalitis in the State of Rio de Janeiro that resulted in death 10 days after the ingestion of A. fulica was reported (Carvalho et al., 2012). After the first report of $A$. 
cantonensis in Brazil by Caldeira et al. (2007), in which it was observed that $66 \%$ of the collected A. fulica snails were infected with such parasite, several other investigations described its presence in A. fulica from harbor areas of this country (i.e., Ilhéus, Bahia; Angra dos Reis, Rio de Janeiro; Paranaguá, Paraná; Navegantes, Santa Catarina) (Carvalho et al., 2012). In the Baixada Santista region (São Paulo, Brazil), an investigation similar to our study was previously performed and $21.7 \%$ of the A. fulica snails analyzed were infected with $A$. cantonensis (Guerino et al., 2017).

The presence of A. fulica snails naturally infected with $A$. cantonensis should serve as a warning to public health authorities about the potential risk of infection to humans. Based on our results $A$. costaricensis did not seem to have much zoonotic importance when the intermediate host was $A$. fulica, since no positive sample was found, but it would be precipitous to say that this parasite does not infect such mollusk. By experimentally infecting $A$. fulica with $A$. costaricensis larvae, it was shown that A. fulica is, in fact, susceptible to the parasite, requiring, however, high levels of larval exposure. Although only $32 \%$ of the samples were found to be positive, the parasite burden in $42 \%$ of the snails ranged from 200 to 1000 third stage larvae (L3) (Carvalho et al., 2003).

These data are useful to public health authorities in order to establish policies related to surveillance and planning of preventive actions. For example, implementing simple wash protocols for vegetables, public education on the dangers of raw mollusk consumption and rat and mollusk control measures may be extremely helpful (Barrett et al., 2016). Considering the potentially lethal nature of angiostrongyliasis and its increasing geographical range, it is important that this disease is given proper consideration.

Keywords: Achatina fulica, Angiostrongylus cantonensis, Angiostrongylus costaricensis, prevalence, city of São Bernardo do Campo

\section{RESUMO}

Angiostrongylus cantonensis e Angiostrongylus costaricensis são nematoides parasitas que residem em roedores e usam gastrópodes como hospedeiros intermediários. Achatina fulica, conhecida como caramujo-gigante-africano, é um hospedeiro intermediário que desempenha importante papel na dispersão de A. cantonensis e A. costaricensis, patógenos zoonóticos que causam, respectivamente, meningoencefalite eosinofílica e angiostrongilíase abdominal em humanos. $O$ objetivo deste estudo foi o de coletar caramujos (A. fulica, $n=90$ ) de oito regiões diferentes (Rudge Ramos, Baeta Neves, Planalto, Demarchi, Dos Alvarengas, Batistini, Montanhão, Rio Grande) da cidade de São Bernardo do Campo (SP) para detecção molecular de A. cantonensis ou A. costaricensis pela técnica de reação em cadeia da polimerase (PCR). As amostras foram processadas em pools $(n=25)$ segundo a região de coleta. Com exceção da região de Baeta Neves, as demais apresentaram caramujos infectados com larvas de nematoides. Seis regiões apresentaram amostras positivas para A. cantonensis. Quatorze (56\%) das 25 amostras em pool apresentaram larvas de nematoides, e 52\% delas (13/25) foram positivas para A. cantonensis. Nenhuma amostra positiva para A. costaricensis foi encontrada. A presença de A. fulica naturalmente infectada por A. cantonensis deve servir como um alerta para as autoridades de saúde pública sobre o risco potencial de infecção para humanos.

Palavras-chave: Achatina fulica, Angiostrongylus cantonensis, Angiostrongylus costaricensis, prevalência, São Bernardo do Campo

\section{REFERENCES}

BARRATT, J.; CHAN, D.; SANDARADURA, I.; MALIK, R. et al. Angiostrongylus cantonensis: a review of its distribution, molecular biology and clinical significance as a human pathogen. Parasitology, v.143, p.10871118,2016
CALDEIRA, R.L.; CARVALHO, O.S.; MENDONÇA, C.L.F.G.; GRAEFF-TEIXEIRA, C. et al. Molecular differentiation of Angiostrongylus costaricensis, Angiostrongylus cantonensis and A. vasorum by polymerase chain reaction and restriction fragment length polymorphism. Mem. Inst. Oswaldo Cruz, v.98, p.1039-1043, 2003. 
CALDEIRA, R.L.; MENDONÇA, C.L.G.F.; GOVEIA, C.O.; LENZI, H.L. et al. First record of molluscs naturally infected with Angiostrongylus cantonensis (Chen, 1935) (Nematoda: Metastrongylidae) in Brazil. Mem. Inst. Oswaldo Cruz, v.102, p.887-889, 2007.

CARVALHO, O.M.; TELES, H.M.S.; MOTA, E.M.; MENDONÇA, C.L.G.F.; LENZI, H.L. Potentiality of Achatina fulica Bowdich, 1822 (Mollusca: Gastropoda) as intermediate host of the Angiostrongylus costaricensis Morera \& Céspedes 1971. Rev.Soc. Bras. Med. Trop., v.36, p.743-745, 2003.

CARVALHO, O.S.; SCHOLTE, R.G.C.; MENDONÇA, C.L.F.; PASSOS, L.K.J.; CALDEIRA, R.L. Angiostrongylus cantonensis (Nematoda, Metastrongyloidea) in molluscs from harbor areas in Brazil. Mem. Inst. Oswaldo Cruz, v.107, p.740-746, 2012.

ESPÍRITO-SANTO, M.C.; PINTO, P.L.S.; MOTA, D.J.G.; GRYSCHEK, R.C.B. The first case of Angiostrongylus cantonensis eosinophilic meningitis diagnosed in the city of São Paulo, Brazil. Rev. Inst. Med. Trop., v.55, p.129-132, 2013.

GASSER, R.B.; CHILTON, N.B.; HOSTE, H.; BEVERIDGE, I. Rapid sequencing of rDNA from single worms and eggs of parasitic helminths. Nucleic Acids Res., v.21, p.25252526, 1993.

GIANNELLI, A.; CANTACESSI, C.; COLELLA, V.; DANTAS-TORRES, F.; OTRANTO, D. Gastropod-borne helminths: a look at the snail-parasite interplay. Trends Parasitol., v.32, p.255-264, 2016.
GRAEEF-TEIXEIRA, C. Expansion of Achatina fulica in Brazil and potential increased risk for angiostrongyliasis. Trans. Rev. Soc. Trop. Med. Hyg., v.10, p.743-744, 2007.

GUERINO, L.R.; PECORA, I.L.; MIRANDA, M.S.; AGUIAR-SILVA, C. et al. Prevalence and distribution of Angiostrongylus cantonensis (Nematoda, Angiostrongylidae) in Achatina fulica (Mollusca, Gastropoda) in Baixada Santista, São Paulo, Brazil. Rev. Soc. Bras. Med. Trop., v.50, p.92-98, 2017.

KLIKST, M.M.; PALUMBO, N.E. Eosinophilic meningitis beyond the Pacific basin: the global dispersal of a peridomestic zoonosis caused by Angiostrongylus cantonensis, the nematode lungworm of rats. Soc. Sci. Med, v.34, p.199212, 1992.

MORASSUTTI, A.L.; TIENGO, S.C.; FERNANDEZ, M.; ASAWANYAWISUTH, K.; GRAEFF-TEIXEIRA, C. Eoshinophilic meningitis caused by Angiostrongylus cantonensis: an emergent disease in Brazil. Mem. Inst. Oswaldo Cruz, v.109, p.399-407, 2014.

PIEN, F.D.; PIEN, B.C. Angiostrongylus cantonensis eosinophilic meningitis. Int. J. Infect. Dis., v.3, p.161-163, 1999.

SILVA, A.C.A; GRA'EFF-TEIXEIRA, C.; ZAHA, A. Diagnosis of abdominal angiotrongyliasis by PCR from sera of patients. Rev. Inst. Med. Trop. S. Paulo, v.45, p.295-297, 2003. 